\title{
IMPACT OF TRADE OPENNESS ON ENVIRONMENT IN CHINA
}

\author{
Wen JUN ${ }^{1}$, Hamid MAHMOOD ${ }^{(1)}{ }^{*}$, Muhammad ZAKARIA \\ School of Economics and Finance, Xian Jiaotong University, Xian, Shaanxi, P. R. China
}

Received 12 February 2019; accepted 11 November 2019

\begin{abstract}
The study investigates the impact of trade openness on pollution in China by applying wavelet-coherence analysis, phase-difference technique and Breitung and Candelon (2006) causality test. The estimated results provide some dynamic association between trade openness and pollutant variables. The results indicate that trade openness has increased pollution in China especially after 2001 when China became member of WTO. It suggests that "pollution haven hypothesis" exists in China. These results imply that trade openness has increased exports which has increased domestic production by increasing the scale of industries, which in turn has increased pollution in the country. The findings of spectral domain causality test show that trade openness causes carbon emission both in short, medium and long runs. It indicates that trade openness forecast carbon emissions in China. The results suggest that China should take suitable measures while following trade openness policy to avoid pollution.
\end{abstract}

Keywords: China, pollution, trade openness, wavelet, phase-difference, causality.

JEL Classifications: F18, Q56.

\section{Introduction}

China initiated the process of trade reforms in 1978, which increased its volume of trade at a remarkable level. The share of trade in China's GDP which was $20.28 \%$ in 1982 shot up to $39.15 \%$ in 2000. After joining WTO in 2001, this share further increased to $63.96 \%$ in 2006 . Today, China has the world's largest trading volume worth $\$ 4.1$ trillion which has made China the largest exporter of goods in the world with $\$ 2.26$ trillion of exports and second largest importer of goods with $\$ 1.84$ trillion imports (World Bank, 2018). This trade liberalization policy along with other economic reforms helped China to enjoy high economic growth rate. Economic growth rate which was 5.17\% in 1981 increased to 14.21 in 1992 and to 14.23 in 2007 (World Bank, 2018). It has increased the per capita income of the people from $\$ 197$ in 1981 to $\$ 959$ in 2000 and to $\$ 8123$ in 2016 . It has reduced the poverty level and has improved the living standards of the people.

*Corresponding author. E-mail: hamid.xjtu@gmail.com 
This high trade has also affected the environment in China. Opponents argue that trade openness has deteriorated the environment as large scale production for exports has turned China into "world factory" and "manufacturing power house" which has increased the energy consumption and hence has increased the carbon emissions. The total value of international trade increased from $\$ 41$ billion from 1982 to $\$ 4100$ billion in 2017 and the total amount of carbon emissions increased from 1580260 (kt) to 10998324 (kt) during the same period. Therefore, it is claimed that high pollution in China is due to its free trade policies. The question arises whether trade openness has increased or decreased pollution in China.

Theoretically, trade openness has three effects on pollution i.e. scale effect, composition effect, and technology effect (Antweiler et al., 2001; Cole \& Elliott, 2003; Copeland \& Taylor, 2004; Farhani et al., 2014). Scale effect suggests that trade increases production, which will increase energy consumption. It will deteriorate environment by emitting carbon emissions. According to composition effect countries change production composition on the basis of their comparative advantage. If trade increases the demand for labor-intensive (capital-intensive) goods then pollution will decrease (increase) because production of labor-intensive (capital intensive) goods does not increase (increases) emissions. It is known as factor endowment hypothesis (FEH). Since developed countries are capital-intensive and less developed countries are labor-intensive, trade will increase pollution in developed countries and will decrease pollution in less developed countries. To attract foreign firms, less developed countries have lenient environmental standards. It will increase pollution in these countries. In literature this concept is called pollution haven hypothesis ( $\mathrm{PHH})$. The net effect of composition effect depends on whether $\mathrm{FEH}$ or $\mathrm{PHH}$ dominates. According to technique effect trade openness will spread environment friendly and energy efficient technology between countries which will decrease pollution. In less developed countries, both scale and composition effects may dominate the technique effect, thus trade may deteriorate environment. In turn, in developed countries technique effect will dominate both scale and composition effects, therefore, the net impact of trade is beneficial to environment.

Several studies have examined the impact of trade intensity on pollution both in China and other countries. Section 2 discusses review of literature in detail. The literature has provided the mixed and controversial effect of trade on pollution. Some studies have shown detrimental while others have shown beneficial effect of trade on pollution. These mixed and inconclusive results could be due to different assumptions, study objectives, econometric methods used, pollution variables, period of analysis, panel vs times series data, cross-sectional units taken, single vs multi-country analysis, etc. It calls for further analysis between trade and pollution in China as it is the largest pollution emitter county in the world and also has world's largest trade volume. The importance of this study is that it uses wavelet technique to analyze trade-pollution linkages as the earlier studies have applied conventional econometric methods to examine the association between trade and pollution. The advantage of wavelet method is that it helps to find lead-lag association between variables across time and frequencies. Further, it helps to identify the interaction between variables in short, medium and long runs, which helps to formulate and implement the policies accordingly. Previously, Jun et al. (2018) have used such approach to analyze the impact of foreign direct investment (FDI) on pollution in China. This paper is extension of Jun et al. (2018) to analyze the impact of trade openness on pollution in China. 
The study proceeds as follows. Next section provides trade openness and pollution patterns in China. Section 2 briefly describes empirical literature. Section 3 discusses the theoretical framework. Section 4 explains the estimated results. Final section provides the conclusion.

\section{Trade pattern and environment condition in China}

Since its reforms from a planned economy to an open economy in 1978, China has witnessed an impressive growth in trade in last thirty years. Figure 1 explains the pattern of exports, imports and total trade of China after economic reforms. The first few years after the reforms, there was no significant increase in trade as it was just $\$ 41$ billion in 1982. Trade has risen dramatically since the beginning of 1990s, with 1992 having $\$ 165$ billion trade volume, which continued throughout 1990s. After joining WTO in 2001, trade quadrupled and reached to $\$ 620.7$ in 2002. During financial crisis of 2008 trade declined from $\$ 2563$ billion in 2008 to $\$ 2207$ billion in 2009 , which recovered and continued to increase. Today, China has the world's largest trading volume worth $\$ 4.1$ trillion which has made China the largest exporter of goods in the world with $\$ 2260$ billion of exports and second largest importer of goods with $\$ 1840$ billion imports (World Bank, 2018).

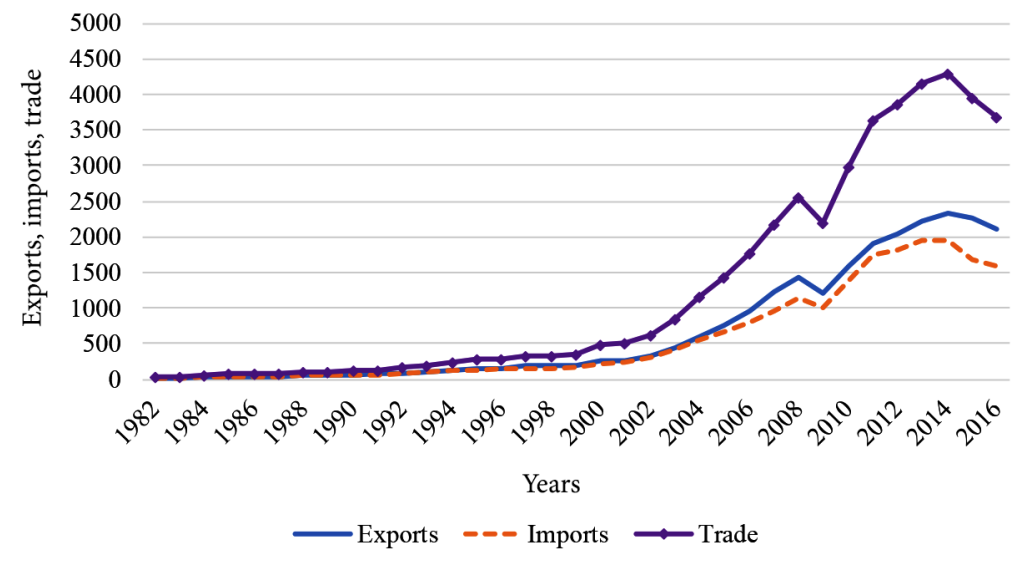

Figure 1. Exports, imports and total trade (Billion \$) (source: World Bank, 2018)

It is argued that high exports have turned China into world factory which has increased pollution in the country. China is the biggest carbon emitter globally in 2017, with $30 \%$ of global $\mathrm{CO}_{2}$ emissions and it will remain on track to peak its carbon emissions by 2030 . Annual average $\mathrm{CO}_{2}$ emissions growth was more than $10 \%$ from 2000 to 2010 and was $3.22 \%$ in 2016 compared to $10.91 \%$ in 2011. Total carbon emissions have increased from 2442431 (kt) in 1990 to 10745401 (kt) in 2016. Alternatively, carbon emissions have increased from 2.15 metric tons per capita in 1990 to 8.09 metric tons per capita in 2016. In 2014, $\mathrm{CO}_{2}$ emissions per capita in China was 7.54 metric tons, far beyond the global average of 4.97 metric tons (World Bank, 2014). It shows that trade has increased pollution in the country. 


\section{Empirical literature}

Empirically, several studies have investigated the effect of trade on environment in different countries. Some studies have found that trade openness improves environment as it reduces pollution (Kanjilal \& Ghosh, 2013; Dogan \& Turkekul, 2016; Antweiler et al., 2001; Boulatoff \& Jenkins, 2010; Copeland \& Taylor, 2003, 2004; Frankel \& Rose, 2005; Birdsall \& Wheeler, 1993; Ferrantino, 1997; Grether et al., 2010; Cole \& Elliott, 2003; Erdogan, 2014; Cherniwchan, 2017). While some other studies have shown that trade has increased pollution and has vandalized the environment (Atici, 2012; Shahbaz et al., 2014; Al-Mulali \& Sheau-Ting, 2014; Kellenberg, 2009; Kukla-Gryz, 2009; Managi \& Kumar, 2009; Dean, 2002; Ang, 2009; Jalil \& Feridun, 2011; Nasir \& Rehman, 2011; Copeland \& Taylor, 1994; Li et al., 2015; Feridun et al., 2006). According to Le et al. (2016) trade decreases pollution in highincome countries and increases pollution in middle and low income countries. Previously, Baek et al. (2009) have also shown that trade improves environment in developed countries and it deteriorates environment in less developed countries as former countries have strong environment regulations and latter countries have lax environmental regulations to attract foreign firms. Similarly, Managi et al. (2009) have shown that trade improves environment in OECD countries and deteriorates environment in non-OECD countries.

According to Chang (2015) trade openness increases carbon emissions in countries which have high corruption and decreases in countries which have low corruption. Previously, Copeland (2005) has also pointed out that trade improves environment but only in the presence of good governance. Damania et al. (2003) have also shown that the impact of trade openness on environment is contingent upon corruption level. Some studies have shown that trade and environment are not related as these studies have found insignificant effect of trade on environment (Farhani et al., 2014; Jalil \& Mahmud, 2009; Jayanthakumaran et al., 2012). Recently, Sun et al. (2019) have shown that the effect of trade openness on pollution varies in different countries. Thus, empirical literature has given inconclusive effect of trade on environment.

Some empirical studies have also been conducted for China. Table 1 gives the summary of these studies. The table reveals that some studies have found the detrimental effect of trade openness on environment (He, 2009; Weber et al., 2008) while some studies have found that trade is beneficial for environment (Dean \& Lovely, 2010). According to Shen (2008) trade openness has different effect on pollutant variables as trade openness increases air pollution while it decreases water pollution. Some studies have used input-output analysis and have shown that international trade has increased pollution in China (e.g. Wang \& Watson, 2008; Weber et al., 2008; Lin \& Sun, 2010; Xu et al., 2011; Yunfeng \& Laike, 2010). Fang et al. (2018) have shown that trade openness decreases industrial wastewater emissions and increases sulfur dioxide emissions in China.

These studies have provided mixed and controversial conclusion because different studies have used different theoretical and econometric models, data types (time series vs panel), different panels of provinces or cities, different estimation techniques and different variables. All studies have explored the effect of trade on environment using control variables. Not a single study is available which has explored the sole effect of trade intensity on pollution. Further, no previous study has used wavelet technique for the analysis. This study will explore the 
sole impact of trade on environment using the wavelet coherence approach as it will better highlight the effect of trade intensity on environment in China.

Table 1. Empirical literature - fact sheet

\begin{tabular}{|c|c|c|c|c|c|}
\hline Studies & $\begin{array}{l}\text { Data } \\
\text { Type(s) }\end{array}$ & $\begin{array}{l}\text { Period of } \\
\text { Analysis }\end{array}$ & $\begin{array}{l}\text { Pollution } \\
\text { Variable(s) }\end{array}$ & $\begin{array}{l}\text { Econometric } \\
\text { Technique }\end{array}$ & Results \\
\hline $\begin{array}{l}\text { Shen } \\
(2008)\end{array}$ & $\begin{array}{l}\text { Panel } \\
\text { data } \\
\text { for } 31 \\
\text { provinces }\end{array}$ & $\begin{array}{l}1993- \\
2002\end{array}$ & $\begin{array}{l}\text { Sulfur dioxide } \\
\left(\mathrm{SO}_{2}\right) \text {, dust, } \\
\text { chemical } \\
\text { oxygen demand } \\
\text { (COD), arsenic, } \\
\text { cadmium }\end{array}$ & $\begin{array}{l}\text { Fixed and } \\
\text { Random } \\
\text { Effect Models }\end{array}$ & $\begin{array}{l}\text { Trade openness has different } \\
\text { effect on pollutant variables. } \\
\text { Trade openness increases } \\
\text { air pollution }\left(\mathrm{SO}_{2} \text { and dust }\right. \\
\text { fall) while it decreases water } \\
\text { pollution (COD, arsenic and } \\
\text { cadmium). }\end{array}$ \\
\hline $\begin{array}{l}\text { Jalil and } \\
\text { Mahmud } \\
(2009)\end{array}$ & $\begin{array}{l}\text { Time } \\
\text { series } \\
\text { data }\end{array}$ & $\begin{array}{l}1975- \\
2005\end{array}$ & $\mathrm{CO}_{2}$ & ARDL & $\begin{array}{l}\text { Trade has insignificant positive } \\
\text { effect on pollution in China. }\end{array}$ \\
\hline $\mathrm{He}(2009)$ & $\begin{array}{l}\text { Panel } \\
\text { data } \\
\text { for } 29 \\
\text { provinces }\end{array}$ & $\begin{array}{l}1992- \\
2003\end{array}$ & $\mathrm{SO}_{2}$ & $\begin{array}{l}\text { Fixed and } \\
\text { random } \\
\text { effect models, } \\
\text { GMM }\end{array}$ & $\begin{array}{l}\text { Direct impact of trade openness } \\
\text { is to reduce pollution in China. } \\
\text { The results support pollution } \\
\text { haven hypothesis in China. }\end{array}$ \\
\hline $\begin{array}{l}\text { Ang } \\
(2009)\end{array}$ & $\begin{array}{l}\text { Time } \\
\text { series } \\
\text { data }\end{array}$ & $\begin{array}{l}1953- \\
2006\end{array}$ & $\mathrm{CO}_{2}$ & ARDL & $\begin{array}{l}\text { Trade openness deteriorates } \\
\text { environment in China. }\end{array}$ \\
\hline $\begin{array}{l}\text { Yunfeng } \\
\text { and Laike } \\
(2010)\end{array}$ & $\begin{array}{l}\text { Time } \\
\text { series } \\
\text { data }\end{array}$ & $\begin{array}{l}1997- \\
2007\end{array}$ & $\mathrm{CO}_{2}$ & $\begin{array}{l}\text { Input-Output } \\
\text { Analysis }\end{array}$ & $\begin{array}{l}\text { Scale and composition effects } \\
\text { have more effect than technique } \\
\text { effect. The net effect of trade } \\
\text { openness is to deteriorate } \\
\text { environment in China. }\end{array}$ \\
\hline $\begin{array}{l}\text { Jalil and } \\
\text { Feridun } \\
\text { (2011) }\end{array}$ & $\begin{array}{l}\text { Time } \\
\text { series } \\
\text { data }\end{array}$ & $\begin{array}{l}1953- \\
2006\end{array}$ & $\mathrm{CO}_{2}$ & ARDL & $\begin{array}{l}\text { Trade openness increases } \\
\text { environmental pollution. }\end{array}$ \\
\hline $\begin{array}{l}\text { Jayantha- } \\
\text { kumaran } \\
\text { et al. } \\
\text { (2012) }\end{array}$ & $\begin{array}{l}\text { Time } \\
\text { series } \\
\text { data }\end{array}$ & $\begin{array}{l}1971- \\
2007\end{array}$ & $\begin{array}{l}\text { Per capita } \mathrm{CO}_{2} \\
\text { emission }\end{array}$ & ARDL & $\begin{array}{l}\text { Trade decreases carbon } \\
\text { emissions in short-run only. }\end{array}$ \\
\hline $\begin{array}{l}\text { Jayantha- } \\
\text { kumaran } \\
\text { and Liu } \\
(2012)\end{array}$ & $\begin{array}{l}\text { Panel } \\
\text { data } \\
\text { foe } 30 \\
\text { provinces }\end{array}$ & $\begin{array}{l}1990- \\
2007\end{array}$ & $\mathrm{SO}_{2}, \mathrm{COD}$ & 2SLS (SEM) & $\begin{array}{l}\text { Scale effect dominates the } \\
\text { technique effect, so pollution } \\
\text { haven hypothesis holds. }\end{array}$ \\
\hline $\begin{array}{l}\text { Zhang } \\
\text { et al. } \\
(2013)\end{array}$ & $\begin{array}{l}\text { Time } \\
\text { series } \\
\text { data }\end{array}$ & $\begin{array}{l}1997 \\
2002 \\
2007\end{array}$ & $\begin{array}{l}\text { Waste water, } \\
\text { COD, nitrogen, } \\
\text { phenol, } \\
\text { cyanide, } \\
\text { chromium, } \\
\text { lead, } \mathrm{SO}_{2}, \mathrm{NOx} \text {, } \\
\text { soot, Dust, } \\
\text { solid waste }\end{array}$ & $\begin{array}{l}\text { Input-Output } \\
\text { Analysis }\end{array}$ & $\begin{array}{l}\text { Trade openness has } \\
\text { deteriorated the environment. }\end{array}$ \\
\hline $\begin{array}{l}\mathrm{Li} \text { and } \mathrm{Tu} \\
(2014)\end{array}$ & \begin{tabular}{|l} 
Panel \\
data for \\
286 cities
\end{tabular} & $\begin{array}{l}2001- \\
2008\end{array}$ & Per capita $\mathrm{SO}_{2}$ & $\begin{array}{l}\text { Fixed Effect } \\
\text { Model }\end{array}$ & $\begin{array}{l}\text { Trade openness does not } \\
\text { deteriorate environment in } \\
\text { China. }\end{array}$ \\
\hline
\end{tabular}


End of Table 1

\begin{tabular}{|c|c|c|c|c|c|}
\hline Studies & $\begin{array}{l}\text { Data } \\
\text { Type(s) }\end{array}$ & $\begin{array}{l}\text { Period of } \\
\text { Analysis }\end{array}$ & $\begin{array}{l}\text { Pollution } \\
\text { Variable(s) }\end{array}$ & $\begin{array}{l}\text { Econometric } \\
\text { Technique }\end{array}$ & Results \\
\hline $\begin{array}{l}\text { Sousa } \\
\text { et al. } \\
(2015)\end{array}$ & $\begin{array}{l}\text { Panel } \\
\text { data for } \\
235 \text { cities }\end{array}$ & $\begin{array}{l}2003- \\
2012\end{array}$ & $\mathrm{SO}_{2}$ & OLS & $\begin{array}{l}\text { Trade openness reduces } \\
\text { pollution. } \\
\text { Trade is beneficial for Chinese } \\
\text { environment. }\end{array}$ \\
\hline $\begin{array}{l}\text { Li et al. } \\
\text { (2016) }\end{array}$ & $\begin{array}{l}\text { Panel } \\
\text { data } \\
\text { for } 28 \\
\text { provinces }\end{array}$ & $\begin{array}{l}1996- \\
2012\end{array}$ & $\begin{array}{l}\mathrm{CO}_{2} \text {, waste } \\
\text { water, solid } \\
\text { waste }\end{array}$ & $\mathrm{ARDL}$ & $\begin{array}{l}\text { Trade deteriorates environment } \\
\text { in China in long run only. }\end{array}$ \\
\hline $\begin{array}{l}\text { Kang } \\
\text { et al. } \\
(2016)\end{array}$ & $\begin{array}{l}\text { Panel } \\
\text { data } \\
\text { for } 30 \\
\text { provinces }\end{array}$ & $\begin{array}{l}1997- \\
2012\end{array}$ & Per capita $\mathrm{CO}_{2}$ & Spatial Model & $\begin{array}{l}\text { Trade decreases carbon } \\
\text { emissions in China. }\end{array}$ \\
\hline $\begin{array}{l}\text { Ertugrul } \\
\text { et al. } \\
(2016)\end{array}$ & $\begin{array}{l}\text { Times } \\
\text { series } \\
\text { data }\end{array}$ & $\begin{array}{l}1971- \\
2011\end{array}$ & $\mathrm{CO}_{2}$ & VECM & $\begin{array}{l}\text { Trade openness increases } \\
\mathrm{CO}_{2} \text { emission in China. Thus, } \\
\text { pollution haven hypothesis is } \\
\text { supported. }\end{array}$ \\
\hline $\begin{array}{l}\text { Lin } \\
(2017)\end{array}$ & $\begin{array}{l}\text { Monthly } \\
\text { data } \\
\text { for } 312 \\
\text { Chinese } \\
\text { Prefec- } \\
\text { tures }\end{array}$ & $\begin{array}{l}2004- \\
2011\end{array}$ & $\begin{array}{l}\mathrm{SO}_{2}, \mathrm{NO}_{2} \\
\text { Aerosol } \\
\text { concentration }\end{array}$ & $\begin{array}{l}\text { OLS, 2SLS } \\
\text { GMM, } \\
\text { Random } \\
\text { Effect, Fixed } \\
\text { Effect }\end{array}$ & $\begin{array}{l}\text { Trade openness has increased } \\
\text { air pollution in China. }\end{array}$ \\
\hline $\begin{array}{l}\text { Fang } \\
\text { et al. } \\
(2018)\end{array}$ & $\begin{array}{l}\text { Panel } \\
\text { data } \\
\text { for } 261 \\
\text { Chinese } \\
\text { cities }\end{array}$ & $\begin{array}{l}2004- \\
2013\end{array}$ & $\begin{array}{l}\text { Waste water, } \\
\mathrm{SO}_{2}\end{array}$ & $\begin{array}{l}\text { Fixed Effect, } \\
\text { GMM, Cup- } \\
\text { FM }\end{array}$ & $\begin{array}{l}\text { Trade openness decreases } \\
\text { industrial wastewater emissions } \\
\text { and increases sulfur dioxide } \\
\text { emissions in China. }\end{array}$ \\
\hline $\begin{array}{l}\text { Fan et al. } \\
(2019)\end{array}$ & $\begin{array}{l}\text { Panel } \\
\text { data } \\
\text { for } 20 \\
\text { industrial } \\
\text { sectors }\end{array}$ & $\begin{array}{l}2000- \\
2014\end{array}$ & $\mathrm{CO}_{2}$ & Fixed Effect & $\begin{array}{l}\text { High trade openness reduces } \\
\text { intensity of emissions in low } \\
\text { carbon sectors. }\end{array}$ \\
\hline
\end{tabular}

\section{Theoretical framework}

\subsection{Wavelet analysis}

Wavelet is a mathematical tool which describes data in various frequency components and then read each component according to its scale. It has advantage over Fourier method as it has both frequency and time resolutions while Fourier technique has only frequency resolution and no time resolution. The continuous wavelet transformation (CWT) of a time series $x_{n}(n=0, \ldots, N-1)$ with uniform time step $\delta t$ and scale (frequency) $s$ is written as

$$
W_{m}^{x}(s)=\frac{\delta t}{\sqrt{s}} \sum_{n=0}^{N-1} x_{n} \psi^{*}\left((n-m) \frac{\delta t}{s}\right), \quad m=0,1, \ldots, N-1 .
$$


Wavelet has different functional forms e.g. Haar, Mexican hat, Morlet, Daubechies, etc. Among these functional forms Morlet wavelet is an important wavelet to study synchronism among time series (Goupillaud et al., 1984). It is written as

$$
\psi_{\eta}(t)=\pi^{-\frac{1}{4}}\left(e^{i \eta t}-e^{-\frac{\eta^{2}}{2}}\right) e^{-\frac{t^{2}}{2}},
$$

where $\psi(t)$ is Morlet wavelet function and $\eta$ is non-dimensional "time" parameter. This wavelet function is analytic. The Fourier transformation of this function is supported in $(0, \infty)$. For $\eta \geq 5$ the term $e^{-\frac{\eta^{2}}{2}}$ becomes negligible and the above function becomes

$$
\psi_{\eta}(t)=\pi^{-\frac{1}{4}} e^{i \eta t} e^{-\frac{t^{2}}{2}}
$$

Now this function has some mass on $(-\infty, 0)$. The wavelet power spectrum can be calculated as $\left|w_{n}^{x}\right|^{2}$, which measures variance at each time and scales.

\subsection{Coherency and phase difference analysis}

The wavelet coherency between two series in time frequency is expressed as

$$
R_{n}(s)=\frac{\left|\phi\left(s^{-1} W_{n}^{x y}(s)\right)\right|}{\phi\left(s^{-1}\left|W_{n}^{x}\right|\right)^{\frac{1}{2}} \phi\left(s^{-1}\left|W_{n}^{y}\right|\right)^{\frac{1}{2}}},
$$

where $\phi$ is smoothed operator at time and scale. The phase difference $\phi_{x, y}$ between $x(t)$ and $y(t)$ is given as (Aguiar-Conraria et al., 2008)

$$
\phi_{x, y}=\tan ^{-1}\left(\frac{u\left(W_{n}^{x y}\right)}{v\left(W_{n}^{x y}\right)}\right),
$$

where $u(v)$ is real (imaginary) part of a complex number. Two series will fluctuate together when phase difference is zero at the identified frequency. The series are in phase (positively correlated) and $y$ leads $x$ when $\phi_{x, y} \in\left[0, \frac{\pi}{2}\right]$, and $x$ leads $y$ when $\phi_{x, y} \in\left[-\frac{\pi}{2}, 0\right]$, respectively. In turn, the series are in anti-phase or out of phase (negatively correlated), when the phase difference is $\pi$ or $-\pi$. If $\phi_{x, y} \in\left[-\pi,-\frac{\pi}{2}\right]$ then $y$ is leading, and if $\phi_{x, y} \in\left[\frac{\pi}{2}, \pi\right]$
then $x$ is leading.

\subsection{Causality test}

Wavelet-based causality mesaure of Olayeni (2016) is based on Rua (2013) wavelet correlation measure. Rua (2013) wavelet correlation measure is expressed as

$$
\rho_{x y}(s, \tau)=\frac{u\left(W_{x y}(s, \tau)\right)}{\sqrt{\left|W_{x}(s, \tau)\right|^{2}\left|W_{y}(s, \tau)\right|^{2}}},
$$


$\rho_{x y}(s, \tau)$ ranges between -1 and 1 i.e. $-1<\rho_{x y}(\tau, s)<1$. This correlation measure shows comovements at time and frequency simultaneously. The CWT-Granger causality test is writen as

$$
G_{x \rightarrow y}(s, \tau)=\frac{u\left(W_{x y}(s, \tau)\right) I_{x \rightarrow y}(s, \tau)}{\sqrt{\left|W_{x}(s, \tau)\right|^{2}\left|W_{y}(s, \tau)\right|^{2}}}
$$

where $I_{x \rightarrow y}(s, \tau)$ is an indicator function and is defined as

$$
I_{x \rightarrow y}(s, \tau)=\left\{\begin{array}{c}
1, \text { if } \phi_{x y}(s, \tau) \int(0, \pi / 2) \cup(-\pi,-\pi / 2) \\
0, \text { otherwise } .
\end{array}\right.
$$

\section{Estimated results}

\subsection{Variable description and data source}

The study has used two measures of trade openness i.e. total trade volume and total trade to GDP ratio to effectively capture its effect on pollution. Generally, trade to GDP ratio is used to measure trade openness (Squalli \& Wilson, 2011). But this measure may fail to take into account trade openness intensity because it can increase, decrease or remain constant due to change in trade and GDP (Busse \& Koeniger, 2015). Therefore, total trade volume is also used to capture trade openness intensity. Pollution is measured by carbon emissions. Two types of carbon emissions are taken i.e. volume of carbon emissions (kt), and per capita carbon emissions (metric tons). Data for trade intensity measures and $\mathrm{CO}_{2}$ variables is collected from the World Bank. Annual data is taken for the period 1982-2016, which is then converted into quarters.

\subsection{Wavelet results}

Wavelet technique is used to find the relationship between two non-stationary series. Thus, examining the stationary properties of the series is not required for the analysis (Aguiar-Conraria et al., 2008; Crowley \& Mayes, 2009; Hallett \& Richter, 2008; Boashash, 2015). For empirical analysis all variables are taken in their logarithm differences. Figure 2 plots the CWT power spectra of the trade and pollution variables, which basically show the power/variance of the variables. It is evident from this figure that trade has fluctuations between 2006 and 2012 at 1-4 quarters (high frequency ${ }^{1}$ or short term), and at 6-16 quarters (medium frequency or medium term to low frequency or long term). Thus, trade has high volatility at same period but at two different frequency levels. In fact, in this period trade increased in China after joining WTO in 2001. The same pattern holds for trade (\% of GDP). $\mathrm{CO}_{2}$ variables have fluctuations at 1-6 quarters between 1995-2012. High fluctuation is also observed in long-run (from 32 quarters onwards).

\footnotetext{
${ }^{1}$ The frequency bands are arbitrary.
} 
Trade (current \$)

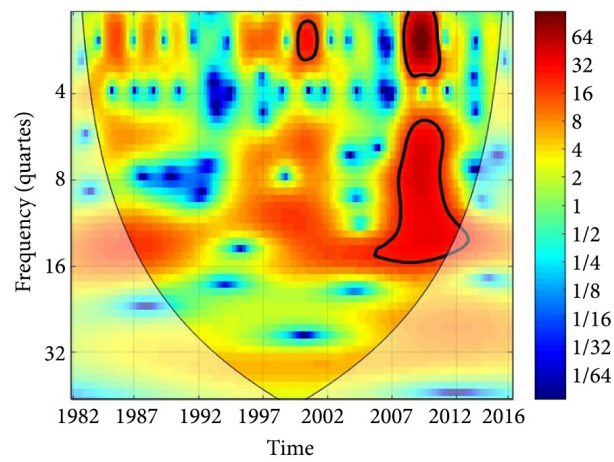

$\mathrm{CO}_{2}$ emissions (kt)

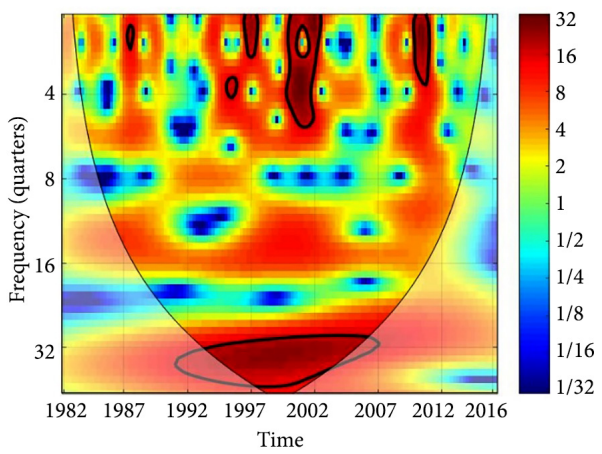

Trade (\% of GDP)

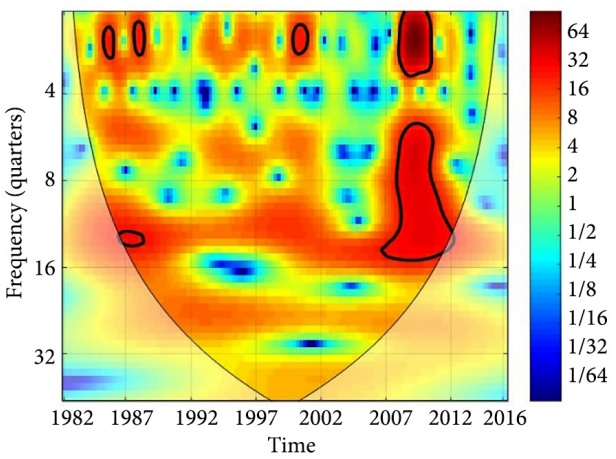

$\mathrm{CO}_{2}$ emissions per capita (metric tons)

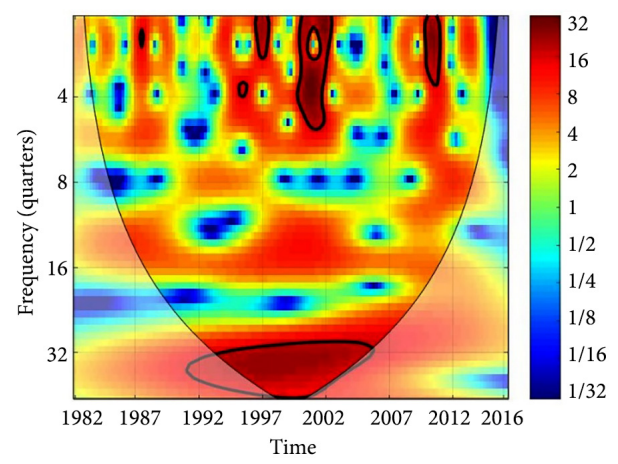

Note: Thick black contour indicates 5\% significance level (against the red noise). Color bar shows the color code for power that goes from low power (in blue) to high power (in red). X-axis shows the time period while the Y-axis shows the frequency (in quarters).

Figure 2. Wavelet power spectrum

\subsection{Coherence and phase difference results}

Wavelet coherency (WTC) plots are provided in Figure 3. These plots show that coherency vary across all frequencies at different times. Co-movements are observed between trade and $\mathrm{CO}_{2}$ emissions (kt) at 8-20 quarters during 1982-1991, and 1997-2016, and at 30 above quarters during 1982-2014. The arrows being oriented up and right imply that trade causes $\mathrm{CO}_{2}$ emissions positively. It suggests that trade increases $\mathrm{CO}_{2}$ emissions. A similar pattern is found for trade and per capita $\mathrm{CO}_{2}$ emissions. However, the red area has decreased in this case. The same findings are observed when trade (\% of GDP) is used. However, the coherency differs across all frequencies at different time periods. Co-movements between two series are strong at relatively higher frequencies. 
Panel A: Trade

Panel B: Trade (\% of GDP)

$\mathrm{CO}_{2}$ emissions (kt)
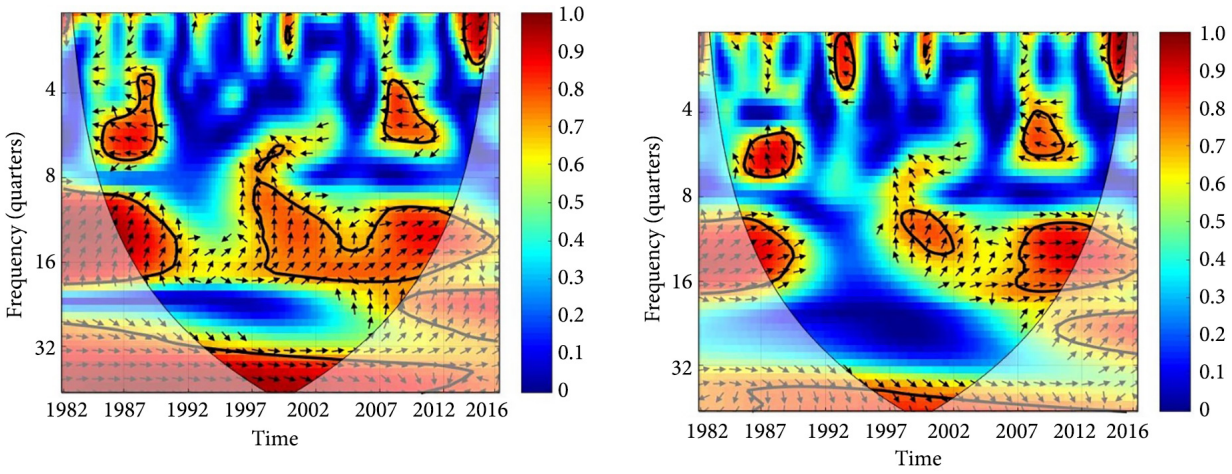

Per Capita $\mathrm{CO}_{2}$ Emissions (metric tons)
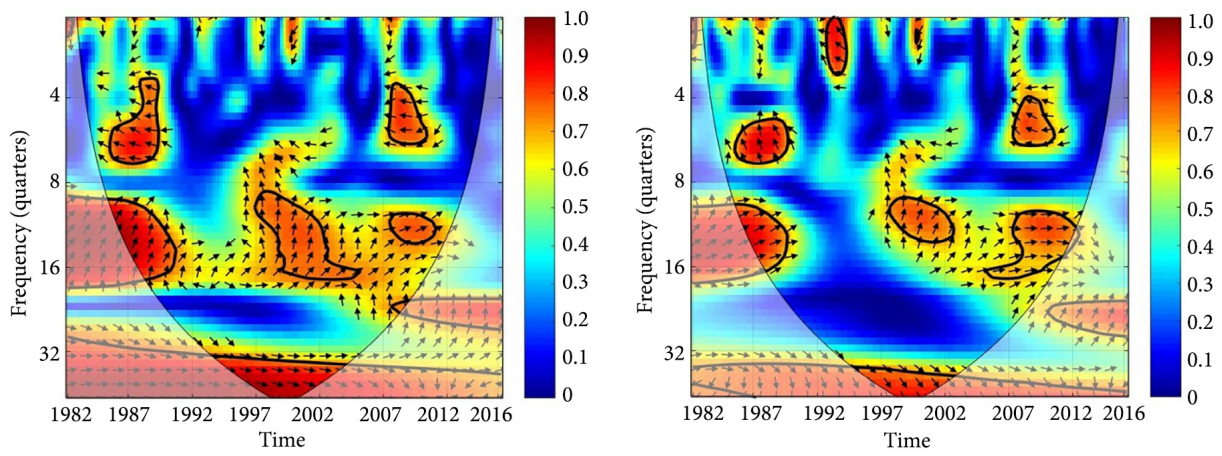

Note: Picture description is same as in Figure 2. Arrows indicate phase difference between two series.

Figure 3. Wavelet coherence plots

\subsection{Causality and correlation results}

Results of wavelet-based causality are provided in Figure 4. The color code moves from blue to red which indicates the degree of causal effects that goes from 0 to 1 . In panel $\mathrm{A}$, a strong causal effect is observed from trade to carbon emissions (kt) between 2007 and 2016 on 22 17 quarter scales. However, this causal effect has become little bit weak in case of per capita carbon emissions. The causality is found to be strong in case of trade (\% of GDP) as shown in Panel B. To be brief, the causality results show that trade openness affects pollution variables in China. 
Panel A: Causality from trade to emissions
Panel B: Causality from trade (\% of GDP) to emissions

$\mathrm{CO}_{2}$ emissions (kt)
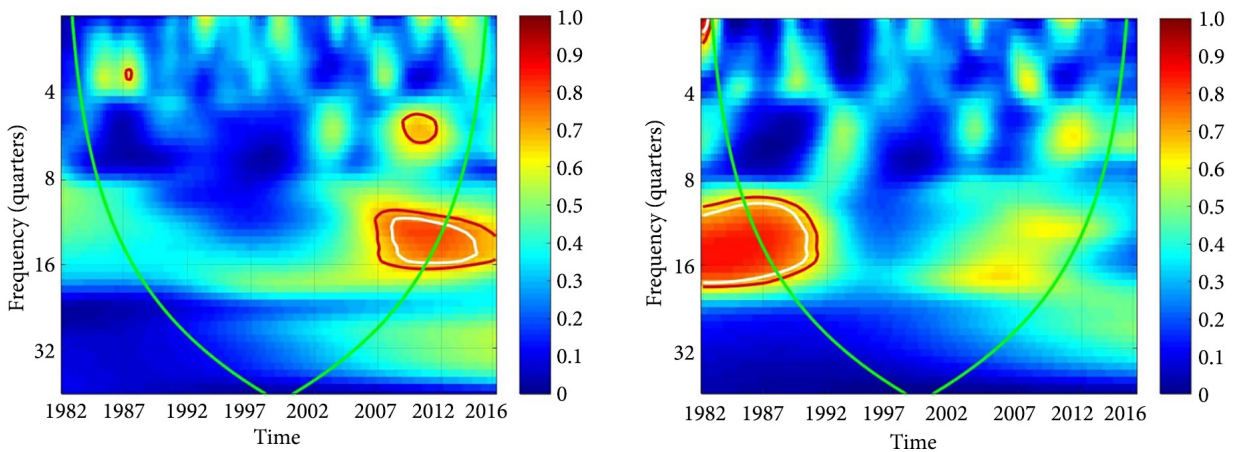

Per Capita $\mathrm{CO}_{2}$ emissions (metric tons)
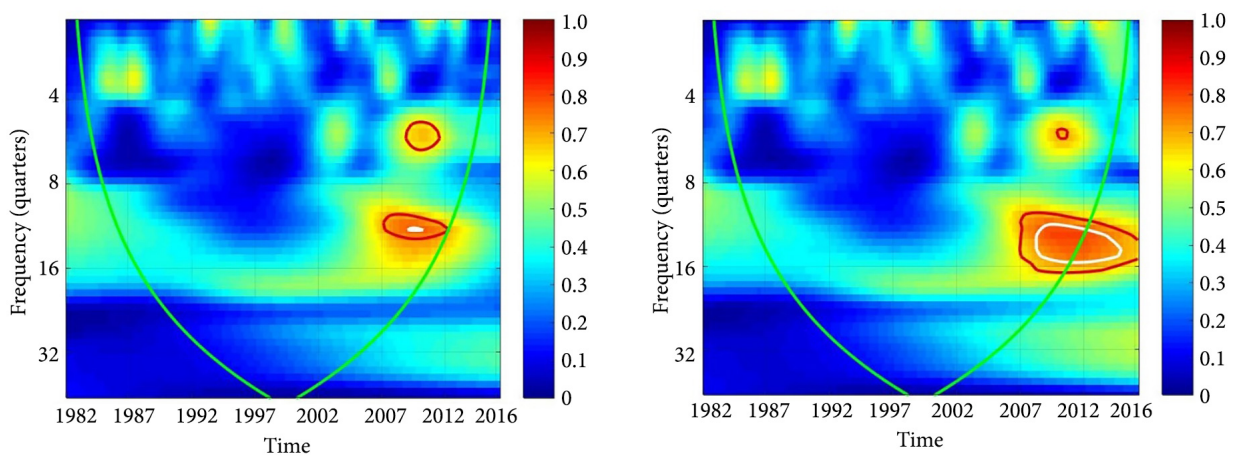

Note: White (red) contour shows statistical significance at 5\% (10\%) level (computed based on 1000 Markov bootstrapped series).

Figure 4. Wavelet based causality from trade (current \$) and trade (\% of GDP) to emissions

Rua (2013) measure of CWT correlation is provided in Figure 5. Correlation of trade with pollution variables is provided in panel A. These plots show positive correlation among variables and this correlation is strong compared to the causal relationship as shown in Figure 4 . The first plot indicates high positive co-movements between trade and $\mathrm{CO}_{2}$ emissions (kt) during 2005-2016 at 10-18 quarters (low frequency bands). This positive co-movement is also persistent at low frequency for whole period. A similar positive correlation is found between trade and per capita emission. Same correlation is found between trade (\% of GDP) and pollution variables (panel B). It again suggests that trade has deteriorated environment in China. 
Panel A: Correlation between trade and emissions
Panel B: Correlation between trade (\% of GDP) and emissions

$$
\mathrm{CO}_{2} \text { emissions (kt) }
$$
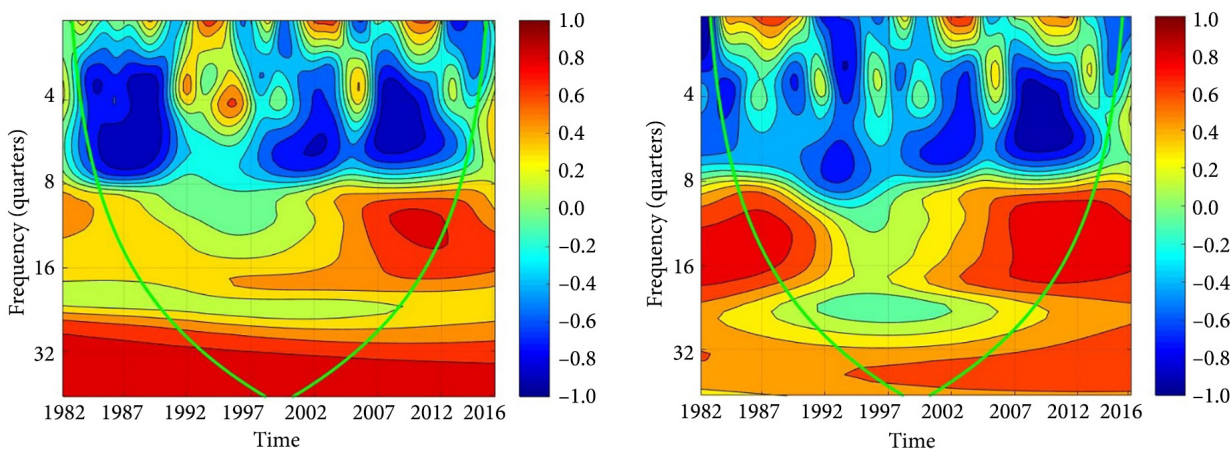

Per Capita $\mathrm{CO}_{2}$ emissions (metric tons)
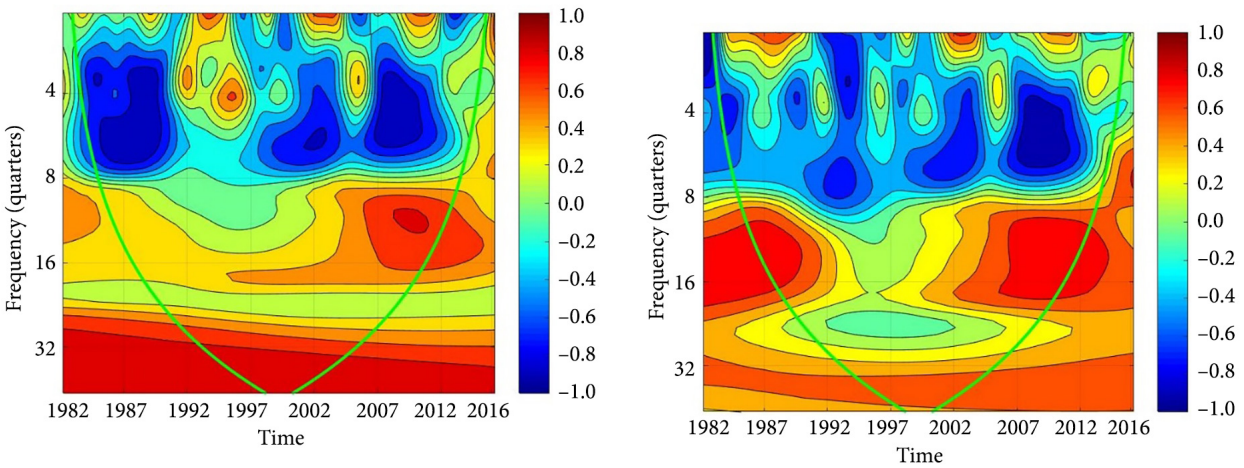

Note: Blue (red) color shows negative (positive) correlations.

Figure 5. Wavelet based correlations (Rua, 2013)

\subsection{Frequency-domain causality test}

The conventional Granger causality test cannot detect causality in different time-scale, therefore, Breitung and Candelon (2006) causality test is used to find the causality among variables. This test examines causality between variables over different time scales i.e. short, medium and long run causality. According to this test the link between two series $\mathrm{N}$ and $\mathrm{M}$ in a stationary VAR model can be expressed as

$$
\begin{aligned}
& \mathrm{M}_{t}=\sum_{i=1}^{p} \rho_{i} \mathrm{M}_{t-i}+\sum_{i=1}^{p} \psi_{i} \mathrm{~N}_{t-i}+\epsilon_{t} \\
& \mathrm{~N}_{t}=\sum_{i=1}^{p} \lambda_{i} \mathrm{~N}_{t-i}+\sum_{i=1}^{p} \chi_{i} \mathrm{M}_{t-i}+v_{t} .
\end{aligned}
$$


The null hypothesis that $N$ does not cause $M$ in the frequency interval $\varpi \epsilon(0, \pi)$, is tested using F-statistics with the distribution $F(2, T-2 p)$. The results from spectral-domain causality test are provided Figure 6. The findings in panel A indicate that trade causes $\mathrm{CO}_{2}$ both at short and long horizons as the values of test statistics exceed the critical values at $5 \%$ level of significance. The same holds for per capita $\mathrm{CO}_{2}$ emissions. It indicates that trade predicts pollution in China. Causality is also found when trade (\% of GDP) is taken.

Panel A: Trade (\$Billions)

Panel B: Trade (\% of GDP)

$\mathrm{CO}_{2}$ emissions (kt)
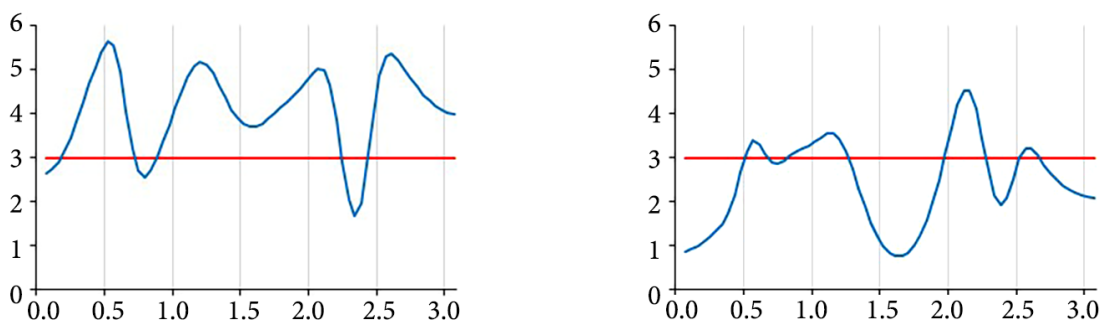

Per Capita $\mathrm{CO}_{2}$ emissions (metric tons)
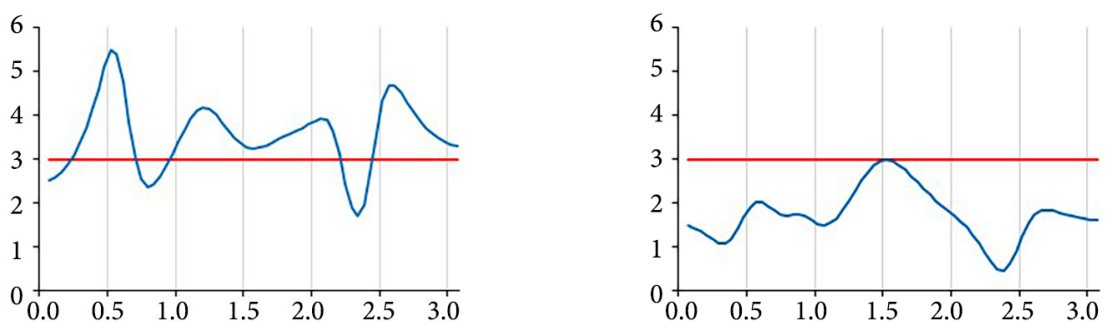

Note: $\mathrm{X}$-axis shows frequencies (omega) and y-axis shows the F-statistics. The horizontal red line shows $5 \%$ critical values.

Figure 6. Wavelet-based causality test

\section{Conclusions}

The paper investigates the impact of trade openness on pollution in China. The analysis is done by applying wavelet technique using data for 1982-2016 time period. The findings show that trade openness has increased pollution in China especially after 2001 when China joined WTO. It shows that "pollution haven hypothesis" exists in China. These results imply that trade openness has increased exports which has increased domestic production by increasing the scale of industries, which, in turn, has increased pollution in China. Causality results show that trade openness causes carbon emissions in short, medium and long runs. It reveals that trade openness forecast carbon emissions in China.

The study has some policy implications. China needs be careful about its trade openness policies to avoid pollution. The government should tighten the environmental regulations to 
prevent pollution. Chinese exports are also driven by foreign companies; these strict rules will prevent these firms from investing in polluting industries, which will improve environment. Moreover, government needs to encourage R\&D investment as it will improve the technical efficiency of local firms, which will help to decrease pollution in the country. These policy implications can be generalized to other developing and emerging economies to avoid pollution. These countries should take appropriate steps to avoid pollution before opening their borders for trade. The main limitation of the study is that it has considered only single determinant of pollution which is trade. Future research can be extended by taking into account some other variables like income, energy consumption, etc.

\section{Author contributions}

All authors carried out empirical analysis and wrote the draft of the paper. Hamid Mahmood collected data and designed the model. Wen Jun was responsible for supervising the analysis and editing the work. Muhammad Zakaria done the supportive work and critically analyzed the work.

\section{Disclosure statement}

Authors do not have any competing financial, professional, or personal conflict of interests from other parties.

\section{References}

Aguiar-Conraria, L., Azevedo, N., \& Soares, M. J. (2008). Using wavelets to decompose the time-frequency effects of monetary policy. Physica A: Statistical Mechanics and Its Applications, 387(12), 2863-2878. https://doi.org/10.1016/j.physa.2008.01.063

Al-Mulali, U., \& Sheau-Ting, L. (2014). Econometric analysis of trade, exports, imports, energy consumption and $\mathrm{CO}_{2}$ emission in six regions. Renewable and Sustainable Energy Reviews, 33, 484-498. https://doi.org/10.1016/j.rser.2014.02.010

Ang, J. B. (2009). $\mathrm{CO}_{2}$ emissions, research and technology transfer in China. Ecological Economics, 68(10), 2658-2665. https://doi.org/10.1016/j.ecolecon.2009.05.002

Antweiler, W., Copeland, B. R., \& Taylor, S. (2001). Is free trade good for the environnement. American Economic Review, 91(4), 877-908. https://doi.org/10.1257/aer.91.4.877

Atici, C. (2012). Carbon emissions, trade liberalization, and the Japan-ASEAN inter-action: A groupwise examination. Journal of the Japanese and International Economies, 26(1), 167-178. https://doi.org/10.1016/j.jjie.2011.07.006

Baek, J., Cho, Y., \& Koo, W. W. (2009). The environmental consequences of globalization: A countryspecific time-series analysis. Ecological Economics, 68(8-9), 2255-2264. https://doi.org/10.1016/j.ecolecon.2009.02.021

Birdsall, N., \& Wheeler, D. (1993). Trade policy and industrial pollutionin Latin America: Where are the pollution havens? Journal of Environment and Development, 2(1), 137-149. https://doi.org/10.1177/107049659300200107

Boashash, B. (2015). Time-frequency signal analysis and processing ( $2^{\text {nd }}$ ed.). Academic Press. 
Boulatoff, C., \& Jenkins, M. (2010). Long-term nexus between openness, income and environmental quality. International Advances in Economic Research, 16(4), 410-418. https://doi.org/10.1007/s11294-010-9283-y

Breitung, J., \& Candelon, B. (2006). Testing for short- and long-run causality: A frequency-domain approach. Journal of Econometrics, 132(2), 363-378. https://doi.org/10.1016/j.jeconom.2005.02.004

Busse, M., \& Koeniger, Y. (2015). Trade and economic growth: A re-examination of the empirical evidence. Economics Bulletin, 35(4), 2862-2876. http://www.accessecon.com/Pubs/EB/2015/Volume35/EB-15-V35-I4-P286.pdf

Chang, S.-C. (2015). The effects of trade liberalization on environmental degradation. Quality \& Quantity, 49(1), 235-253. https://doi.org/10.1007/s11135-013-9984-4

Cherniwchan, J. (2017). Trade liberalization and the environment: Evidence from NAFTA and U.S. manufacturing. Journal of International Economics, 105, 130-149. https://doi.org/10.1016/j.jinteco.2017.01.005

Cole, M. A., \& Elliott, R. J. R. (2003). Determining the trade-environment composition effect: The role of capital, labour and environmental regulations. Journal of Environmental Economics and Management, 46(3), 363-383. https://doi.org/10.1016/S0095-0696(03)00021-4

Copeland, B. R. (2005). Policy endogeneity and the effects of trade on the environment. Agricultural and Resource Economics Review, 34(1), 1-15. https://doi.org/10.1017/S1068280500001532

Copeland, B., \& Taylor, M. (2003). Trade and the environment: Theory and evidence. Princeton University Press. https://doi.org/10.1515/9781400850709

Copeland, B., \& Taylor, M. (2004). Trade, growth and the environment. Journal of Economic Literature, 42(1), 7-71. https://doi.org/10.1257/.42.1.7

Copeland, B. R., \& Taylor, M. S.(1994). North-south trade and the environment. Quarterly Journal of Economics, 109(3), 755-787. https://doi.org/10.2307/2118421

Crowley, P. M., \& Mayes, D. G. (2009). How fused is the euro area core? An evaluation of growth cycle co-movement and synchronization using wavelet analysis. OECD Journal: Journal of Business Cycle Measurement and Analysis, 2008(1), 63-95. https://doi.org/10.1787/jbcma-v2008-art4-en

Damania, R., Fredriksson, P., \& List, J. (2003). Trade liberalization, corruption, and environmental policy formation: Theory and evidence. Journal of Environmental Economics and Management, 46(3), 490-512. https://doi.org/10.1016/S0095-0696(03)00025-1

Dean, J. M. (2002). Does trade liberalisation harm the environment? A new test. Canadian Journal of Economics, 35(4), 819-842. https://doi.org/10.1111/0008-4085.00155

Dean, J. M., \& Lovely, M. E. (2010). Trade growth, production fragmentation, and China's environment. In China's growing role in world trade (NBER Chapters, pp. 429-469). National Bureau of Economic Research, Inc. http://www.nber.org/chapters/c10469.pdf

Dogan, E., \& Turkekul, B. (2016). $\mathrm{CO}_{2}$ emissions, real output, energy consumption, trade, urbanization and financial development: Testing the EKC hypothesis for the USA. Environmental Science and Pollution Research, 23(2), 1203-1213. https://doi.org/10.1007/s11356-015-5323-8

Erdogan, A. M. (2014). Bilateral trade and the environment: A general equilibrium model based on new trade theory. International Review of Economics and Finance, 34, 52-71. https://doi.org/10.1016/j.iref.2014.07.003

Ertugrul, H. M., Cetin, M., Seker, F., \& Dogan, E. (2016). The impact of trade openness on global carbon dioxide emissions: Evidence from the top ten emitters among developing countries. Ecological Indicators, 67, 543-555. https://doi.org/10.1016/j.ecolind.2016.03.027

Fan, B., Zhang, Y., Li, X. \& Miao, X. (2019). Trade openness and carbon leakage: Empirical evidence from China's industrial sector. Energies, 12(6), 1101. https://doi.org/10.3390/en12061101 
Fang, Z., Huang, B., \& Yang, Z. (2018). Trade openness and the environmental Kuznets Curve: Evidence from Cities in the People's Republic of China (Working Paper No. 882). Asian Development Bank Institute. https://www.adb.org/sites/default/files/publication/464116/adbi-wp882.pdf

Farhani, S., Chaibi, A., \& Rault, C. (2014). $\mathrm{CO}_{2}$ emissions, output, energy consumption, and trade in Tunisia. Economic Modelling, 38, 426-434. https://doi.org/10.1016/j.econmod.2014.01.025

Feridun, M., Ayadi, F. S., \& Balouga, J. (2006). Impact of trade liberalization on the environment in developing countries: The case of Nigeria. Journal of Developing Societies, 22(1), 39-56. https://doi.org/10.1177/0169796X06062965

Ferrantino, M. (1997). International trade, environmental quality and public policy. World Economy, 20(1), 43-72. https://doi.org/10.1111/1467-9701.00057

Frankel, J., \& Rose, A. (2005). Is trade good or bad for the environment? Sorting out the causality. The Review of Economics and Statistics, 87(1), 85-91. https://doi.org/10.1162/0034653053327577

Goupillaud, P., Grossmann, A., \& Morlet, J. (1984). Cycle-octave and related transforms in seismic signal analysis. Geoexploration, 23(1), 85-102. https://doi.org/10.1016/0016-7142(84)90025-5

Grether, J., Mathys, N. A., \& de Melo, J. (2010). Global manufacturing $\mathrm{SO}_{2}$ emissions: Does trade matter? Review of World Economics, 145(4), 713-729. https://doi.org/10.1007/s10290-009-0033-2

Hallett, A. H., \& Richter, C. (2008). Have the Eurozone economies converged on a common European cycle? International Economics and Economic Policy, 5(1-2), 71-101. https://doi.org/10.1007/s10368-008-0113-0

$\mathrm{He}, \mathrm{J}$. (2009). China's industrial $\mathrm{SO}_{2}$ emissions and its economic determinants: EKC's reduced vs. structural model and the role of international trade. Environment and Development Economics, 14(2), 227-262. https://doi.org/10.1017/S1355770X0800452X

Jalil, A., \& Feridun, M. (2011). The impact of growth, energy and financial development on the environment in China: A cointegration analysis. Energy Economics, 33(2), 284-291.

https://doi.org/10.1016/j.eneco.2010.10.003

Jalil, A., \& Mahmud, S. F. (2009). Environment Kuznets curve for $\mathrm{CO}_{2}$ emissions: A cointegration analysis for China. Energy Policy, 37(12), 5167-5172. https://doi.org/10.1016/j.enpol.2009.07.044

Jayanthakumaran, K., \& Liu, Y. (2012). Openness and the environmental Kuznets curve: Evidence from China. Economic Modelling, 29(3), 566-576. https://doi.org/10.1016/j.econmod.2011.12.011

Jayanthakumaran, K., Verma, R., \& Liu, Y. (2012). $\mathrm{CO}_{2}$ emissions, energy consumption, trade and income: A comparative analysis of China and India. Energy Policy, 42, 450-460. https://doi.org/10.1016/j.enpol.2011.12.010

Jun, W., Zakaria, M., Shahzad, S. J. H., \& Mahmood, H. (2018). Effect of FDI on pollution in China: New insights based on wavelet approach. Sustainability, 10(11), 1-20. https://www.mdpi.com/2071-1050/10/11/3859/pdf

Kang, Y.-Q., Zhao, T., \& Yang, Y.-Y. (2016). Environmental Kuznets curve for $\mathrm{CO}_{2}$ emissions in China: A spatial panel data approach. Ecological Indicators, 63, 231-239.

https://doi.org/10.1016/j.ecolind.2015.12.011

Kanjilal, K., \& Ghosh, S. (2013). Environmental Kuznets curve for India: Evidence from tests for cointegration with unknown structural breaks. Energy Policy, 56, 509-515. https://doi.org/10.1016/j.enpol.2013.01.015

Kellenberg, D. K. (2009). An empirical investigation of the pollution haven effect with strategic environment and trade policy. Journal of International Economics, 78(2), 242-255. https://doi.org/10.1016/j.jinteco.2009.04.004

Kukla-Gryz, A. (2009). Economic growth, international trade and air pollution: A decomposition analysis. Ecological Economics, 68(5), 1329-1339. https://doi.org/10.1016/j.ecolecon.2008.09.005 
Le, T. H., Chang, Y., \& Park, D. (2016). Trade openness and environmental quality: International evidence. Energy Policy, 92, 45-55. https://doi.org/10.1016/j.enpol.2016.01.030

Li, P., \& Tu, Y. (2014). The impacts of openness on air quality in China. Environment and Development Economics, 19(2), 201-227. https://doi.org/10.1017/S1355770X13000557

Li, T., Wang, Y., \& Zhao, D. (2016). Environmental Kuznets Curve in China: New evidence from dynamic panel analysis. Energy Policy, 91, 138-147. https://doi.org/10.1016/j.enpol.2016.01.002

Li, Z., Xu, N., \& Yuan, J. (2015). New evidence on trade-environment linkage via air visibility. Economics Letters, 128, 72-74. https://doi.org/10.1016/j.econlet.2015.01.014

Lin, B. Q., \& Sun, C. W. (2010). Evaluating carbon dioxide emissions in international trade of China. Energy Policy, 38(1), 613-621. https://doi.org/10.1016/j.enpol.2009.10.014

Lin, F. (2017). Trade openness and air pollution: City-level empirical evidence from China. China Economic Review, 45, 78-88. https://doi.org/10.1016/j.chieco.2017.07.001

Managi, S., \& Kumar, S. (2009). Trade-induced technological change: Analyzing economic and environmental outcomes. Economic Modelling, 26(3), 721-732.

https://doi.org/10.1016/j.econmod.2009.02.002

Managi, S., Hibiki, A., \& Tsurumi, T. (2009). Does trade openness improve environmental quality? Journal of Environmental Economics and Management, 58(3), 346-363. https://doi.org/10.1016/j.jeem.2009.04.008

Nasir, M., \& Rehman, F. (2011). Environmental Kuznets Curve for carbon emissions in Pakistan: An empirical investigation. Energy Policy, 39(3), 1857-1864.

https://doi.org/10.1016/j.enpol.2011.01.025

Olayeni, O. R. (2016). Causality in continuous wavelet transform without spectral matrix factorization: Theory and application. Computational Economics, 47(3), 321-340. https://doi.org/10.1007/s10614-015-9489-4

Rua, A. (2013). Worldwide synchronization since the nineteenth century: A wavelet-based view. Applied Economics Letters, 20(8), 773-776. https://doi.org/10.1080/13504851.2012.744129

Shahbaz, M., Khraief, N., Uddin, G. S., \& Ozturk, I. (2014). Environmental Kuznets curve in an open economy: A bounds testing and causality analysis for Tunisia. Renewable and Sustainable Energy Reviews, 34, 325-336. https://doi.org/10.1016/j.rser.2014.03.022

Shen, J. (2008). Trade liberalization and environmental degradation in China. Applied Economics, 40(8), 997-1004. https://doi.org/10.1080/00036840600771148

Sousa, J. D., Hering, L., \& Poncet, S. (2015). Has trade openness reduced pollution in China? (CEPII Working Paper).

Squalli, J., \& Wilson, K. (2011). A new measure of trade openness. The World Economy, 34(10), 17451770. https://doi.org/10.1111/j.1467-9701.2011.01404.x

Sun, H., Clottey, S. A., Geng, Y., Fang, K., \& Amissah, J. C. K. (2019). Trade openness and carbon emissions: Evidence from Belt and Road Countries. Sustainability, 11(9), 2682. https://doi:10.3390/su11092682

Wang, T., \& Watson, J. (2008). China's carbon emissions and international trade: Implications for post2012 policy. Climate Policy, 8(6), 577-587. https://doi.org/10.3763/cpol.2008.0531

Weber, C. L., Peters, G. P., Guan, D., \& Hubacek, K. (2008). The contribution of Chinese exports to climate change. Energy Policy, 36(9), 3572-3577. https://doi.org/10.1016/j.enpol.2008.06.009

World Bank. (2014). World Development Indicators. http://datatopics.worldbank.org/world-development-indicators/

World Bank. (2018). World Development Indicators. http://datatopics.worldbank.org/world-development-indicators/ 
Xu, M., Li, R., Crittenden, J. C., \& Chen, Y. (2011). $\mathrm{CO}_{2}$ emissions embodied in China's exports from 2002 to 2008: A structural decomposition analysis. Energy Policy, 39(11), 7381-7388. https://doi.org/10.1016/j.enpol.2011.08.068

Yunfeng, Y. F., \& Laike, Y. K. (2010). China's foreign trade and climate change: A case study of $\mathrm{CO}_{2}$ emissions. Energy Policy, 38(1), 350-356. https://doi.org/10.1016/j.enpol.2009.09.025

Zhang, C., Beck, M. B., \& Chen, J. (2013). Gauging the impact of global trade on China's local environmental burden. Journal of Cleaner Production, 54(1), 270-281.

https://doi.org/10.1016/j.jclepro.2013.04.022 